\title{
DEVELOPMENT OF INFOLOGICAL MODELING METHODS IN SOCIAL COMMUNICATION PROBLEMS FOR CREATION PERSPECTIVE COMPLETED MATERIALS
}

\section{РОЗВИТОК МЕТОДІВ ІНФОЛОГІЧНОГО МОДЕЛЮВАННЯ В ЗАДАЧАХ СОЦІАЛЬНОЇ КОМУНІКАЦІЇ ДЛЯ СТВОРЕННЯ ПЕРСПЕКТИВНИХ СКЛАДЕНИХ МАТЕРІАЛІВ}

\section{Georg Baranov ${ }^{1}$ \\ Olena Komisarenko ${ }^{2}$}

DOI: https://doi.org/10.30525/978-9934-588-15-0-50

Abstract. Due to the spread of information and telecommunication technologies, social communication gets various forms of citizens rapid activity. The subject of this study is the models, methods and tools of information technology that allow us to focus the efforts of each system intellectual agent on a synergistic interaction discourse for solving global noosphere problems. The methodology for strategic integration of public knowledge at each management decision-making step involves describing and fixing in the unified form protective actions against future risks for ecological life forms on Earth planet. The purpose of the research is the development of infological modeling methods for creation of perspective composite materials with thermodynamic influence on the application of the necessary and sufficient sequential properties processes, which satisfy the set social requirements for the future ITS exploitation. The main criterion, which integrates partial technical and technological solutions, is to determine the single desired safety of life in each city and in all environmental fields. Minimizing the cost of heterogeneous resources is defined as the search for effective methods for modeling complex dynamic systems in the conditions of forecast states of external dynamic-global environment non-stationary diverse phenomena. Tasks and orders transformation for

\footnotetext{
${ }^{1}$ Doctor of Technical Sciences, Professor,

Department of Information Systems and Technologies,

National Transport University, Ukraine

${ }^{2}$ Assistant Lecturer, Department of Information Systems and Technologies,

National Transport University, Ukraine

(C) Georg Baranov, Olena Komisarenko
} 
future technologies modeling into a complex technology utilization of accumulated waste without secondary pollution and utilizes the accumulated waste. In the processes of thermodynamic self-propagating synthesis, the processing of substances - local contamination into perspective composite materials for different transport industries takes place. The principles of NM modeling and "cloud" participation of dispersed intellectual agents of different hierarchical levels of multi-agent manufacturing organizations are analyzed. The following components of the KM-PD system are determined. Integrated self-organization tools have linguistic applications to accelerate communication. Real-time language controls manage and filter information flow. The means of predicative unified logic formalize the innovative laws of the resulting technical and technological solutions. Processor infological models and experience of their application provide conditions for large-scale implementations of machines and work of future industrial environmentally friendly industries. The means of knowledge bases adaptive self-organization stimulate the further development of problem situations infological modeling methods, which, thanks to the proposed tools, turn into current resource-efficient technological processes. The command and control management principles for software and hardware complexes for the operational modeling of future variants of heterogeneous processes interaction are proposed. The proposed KM-PD system implements the synthesis of adequate actual information technologies models and repositories. The proposed knowledge representation models are intended to intensify the processes of ecological diversity global protection.

\section{1. Вступ}

Розвиток сучасних галузей комп'ютеризованих технологій людської діяльності все більше залежить від методів: забезпечення обчислювальної якості; гарантованого рівня надійності; поточної відмовостійкості інструментальних засобів; визначення умов конкурентної спроможності й живучості. Існуючі традиційні інформаційні технології (IT) та системи оперативного управління не зважаючи на значне розширення Internet, як соціальної комунікації вже не задовольняють потреб майбутніх виробничих та організаційних завдань. Бажання на перспективне створення шляхом завчасного покращення конкретно оцінюваних станів не перетворюється у швидко отримані матеріали, 
продукти, товари, послуги, тому, що всі складові частки змінюються у просторі та часі єдиного просторово-часового континууму (ПЧК) Всесвіту.

Перспективні об'єкти майбутнього застосування можливо класифікувати на складні динамічні системи (СДС), що реагують на передбачені функціональні впливи гетерогенних факторів нестаціонарного середовища [1-4]. Результати дії ризикованих збурень на контактні поверхні СДС обумовлюють реальні відхилення контрольованих цільових станів. Вони разом з передбаченими засобами захисту на рівні спеціальних матеріалів формують бажаний стан, як гарантовану живучість та функціональну стійкість інноваційних СДС. Таким чином за замовлень ведучих галузей, включаючи Intelligent Transportation Systems (ITS) застосування перспективних складених матеріалів (ПСМ) гостро потрібно, бо інакше втрачаються темпи розвитку безпечного, розумного, екологічного, мобільного транспорту. Тому соціальні комунікації та засоби Internet об'єднують зусилля інтелектуалів на інтенсивний пошук відповідних критеріїв оцінювання та методів комплексного моделювання для забезпечення існування ефективних технологій майбутнього. Лише за умов існування техніко-технологічних рішень (ТТР) всі замовлені на майбутнє показники якості та ефективності експлуатаційних режимів ПСМ не вийдуть з зони Парето за обставин конструктивного витримування збурень від зовнішнього оточуючого середовища (ЗНОС). До наближення наступного горизонту проблемні ситуації поки ще прогнозуємо, передбачуємо й від цього проектуємо форми захисту СДС на вже існуючих програмно-апаратних комплексах (ПАК) типу MatLab, MatCad, Mapl, DataManing, САПР, тощо. Будь-яке подальше покращення досягається завдяки розробці ТТР та застосування адекватних цифрових робочих оперативних моделей (РОМ), що разом з типовими програмними модулями (ТПМ) засобів IT, допомагають реалізовувати відповідні явні процеси.

\section{2. Методологія стратегічної інтеграції знань}

При збільшенні прогнозного інтервалу передбачення та кроку прийняття управлінських рішень, наприклад, фінансування захисних дій від майбутніх ризиків зі збігом небажаних обставин у глобальних формах життя на планеті зростає складність загроз й масштаб витрат 
ресурсів на захист від негараздів. Тому подолання реальної складності ризиків й невизначеності можливе завдяки ієрархічній самоорганізації соціальної комунікації для чого потрібна побудова ефективних інтерфейсних інфологічних моделей для гетерогенного використання наявних ПАК та додаткових спеціалізованих моделей і методів. Стратегічні досягнення у сфері автоматизації виконання бажаних функцій і завдань виробничого й організаційного управління у перспективних багаторівневих структурах інноваційних СДС будуть виникати на основі знання ТТР, що гарантують створення ПСМ. Досягнення очікуваних значень замовлених властивостей у заплановані терміни значно оптимізує повні витрати ресурсів на принципах самонавчання та Agile [1] й тому є безумовно актуальною.

Мета. Розвиток методів інфологічнго моделювання в задачах із термодинамічних впливів на процеси створення ПСМ, що задовольняють заданим вимогам достатніх властивостей на експлуатацію.

\section{3. Задачі соціальної комунікації}

Авторська ідея дієвого об'єкта (АВІДО) стосовно теми дослідження процесів створення інноваційних матеріалів полягає у триєдності інформаційних відношень при розв'язанні складних (проблемнихнетривіальних) задач. Вони належать єдиній метрологічній системі вимірювання параметрів [1] та випробування техніко-технологічних рішень (ТТР) [2] засобами КМ-ПД.

Формалізовано методи та методики IT для процесів інфологічного моделювання ПІМ та ергатичного пошуку ефективних управлінських TТР за інтегральними критеріями безпеки. КМ-ПД явно не втручається у сфери технології реального виробництва складених матеріалів. Але всі моделюємі ТТР імітуємо без викидів в атмосферу та теплових загроз для життя.

Нагадаємо формальне визначення поняття «задача»:

$$
\theta=<\zeta, Z, F, \delta>,
$$

де $\theta$ - тема або початковий інформаційний об'єкт задачної системи;

$\zeta$ - перелік цілевказівок у вигляді комплексу інструкцій-настанов;

$Z$ - задачний комплекс станів, що у вигляді $Z_{0}$ початкового, проміжного $Z_{i}$ поточного та кінцевого-цільового $Z_{n}$ станів, вже фіксують 
сутність, особливості та специфіку даного класу перетворень у межах мікропроцесорних управлінських дій ПАК згідно ТTР інтелектуального агента системи (IAS), що реалізує комплексне моделювання;

$F$ - функціональний комплекс правил продукції, що заздалегідь вже визначено згідно алгоритму розв'язку задачі у вигляді послідовності типових операторів, щоб досягати $\zeta_{n}$ мети - кінцевого результату.

$\sigma$ - початковий символ АВІДО задачної системи для технологій автоматного переходу від початкового стану у термінальний кінцевий з фіксуванням ТTР.

Авторська розробка сутності, особливості та специфіки (СОC) в інформаційних технологіях (IT) для запропонованого нами ПАК КМ-ПД враховує проблемну галузь діяльності ПЕВО. Створення складених матеріалів полягає у інтерпретації вхідних понять (речень), людських слів, в формі кодів.

Сутність ПІМ КМ-ПД полягає у цілеспрямованому перенесенні кожного ключового поняття з цілісної порції завдання на мові директивно-командного управління у іншу сферу СIП IT, де продовження мовної теми IAS далі раціонально реалізує автомат-програма ДУМ 3 спеціалізованими інформаційними процедурами. Під час пошуків керованого «бігання» (пряме й зворотне у межах комунікаційного інтерфейсу) можливо назвати діскурсивним (від лат. discursus; англ. discourse; франц. discours; нім. diskurs; італ. discorso). Першим «дискурс про метод» («Discours de la method» у 1637 р.) визначив Р. Декарт. В нашому автоматизованому діалозі реально $є$ пара колообігів: у нервовій мережі IAS є ПЕВО реальний розмовник; у цифрових автоматах ПАК КМ-ПД, що розпізнають ДУМ значущості означеного. Багаторівневі структури згідно заздалегідь варіфікованих правил, принципів, моделей, методів та засобів IT забезпечують СІП та задану функцію у конкретно описаних умовах задачі моделювання. Внутрішню приховану, або неявну за ознаками замовчування інтелектом КМ-ПД й конкретно ДУМ програмою, але раціональну (ratio intelectus майже оптимальну за локальними критеріями) форму реалізує в цілому ПАК КМ-ПД згідно використання особливого (N) змістовного завдання.

Показники запропонованих методів автоматизації залежать не лише від обізнаності конкретного IAS-користувача-автора ABIДО, а також від накопичених ресурсів ПАК з КМ-ПД спроможністю вико- 
ристовувати власні внутрішні й зовнішні «хмарні» ресурси інтегрованого середовища інформатизованої ноосфери. Практика застосування запропонованих принципів discourse у інноваційних IT сприяє подальшому розвитку математизованого знання у роботах з одночасним інтегрованим ефектом самоорганізації суспільства, де враховуються правильно зроблене надбання у вигляді досвіду особистостей, що спроможні генерувати власні АВІДО. Опис досвіду IAS у лінгвістичній прагматиці взаємодії з ПАК КМ-ПД сприяє розвитку функціональної семіотики. Накопичене характеризує інтеграційні дії у різних середовищах, ситуаціях, явищах, які змінюються згідно людської діяльності у межах виробничих та організаційних сферах. Наприклад, ПЕВО ITS. Глобальні проблеми чи значно ускладнені актуальні задачі практики можливо успішно формалізувати за варіантами «Мета-проблема-засоби ТТР». Саме ratio intelectus у вигляді обізнаної ментальності (mens - розум IAS та одночасно spiritis життєва сила за допомого КМ-ПД прискорювача) забезпечує реальність визначеного у формі АВІДО. Кодовані описи подальших причинно-наслідкових кроків 3 ситуативно оптимальним вибором ефективних ресурсів, засобів і способів дії (відповідно до можливих змін критеріїв за інноваційними системами цінностей) починають домінувати над «застарілими попередніми ТTР. Пошуки минулих фаз або спроб Problem зменшення загроз від ризиків та небезпек ЗНОС поки ще не завершились значним охоплюючим успіхом.

Конкретний автоматизований дискурс семіотичної діяльності в процесах ергатичного моделювання об'єктів практики слід визначати як складене комунікативне явище самоорганізації пари природного IAS та штучного КМ-ПД інтелектів. В цьому процесі взаємо-самоорганізації учасників на всіх ієрархічних рівнях виробничої та організаційної діяльності відбуваються вкладення еквівалентних понять-структурних фрагментів та утворення нових понять майбутньої метамови для наступних поки ще невизначених горизонтів розвитку інформаційного суспільства. Логіка якого в свою чергу змінюється.

Таким чином науковий дискурс пішов далі від традиційного експертного аналізу взаємозв'язків в кожному окремому описі локального факту до комплексних складних гетерогенних відносин на більш тривалих просторових й часових континуумах, що разом визначають 
єдність Всесвіту, цілісність, взаємозалежність розвитку як СДС так й ЗНОС у множині універсуумі.

Запропоновані моделі, методи та засоби застосування ПІМ в ПАК КМ-ПД не лише ілюструють правила й принципи прямих й зворотних динамічних зв'язків між природним IAS (аналогово-лінгвістичним) розумом та штучним результатом продуктом сучасного IT у вигляді спільно формалізованих ТТР. Саме фактично інноваційна звітова форма ТТР розширює майбутні горизонти. Сенс фіксації взаємовідносин значущості є увага ключової ролі інноваційної частини АВІДО (науковий крок до новизни $з$ доказами істинності) у проблемних Big Data. Відомі документи мають багато заперечень, обмежень, висловлювань неможливості розв'язання проблем, що актуальна особливо для інформаційного суспільства в цілому. Отриманий у дискурсі значущий сенс має пояснення раціонального маршруту у майбутнє з застосуванням реальних ресурсів згідно визначеного документа Plan (лише один етап Agile принципів). Всім відома різниця $\Delta(t)=\mid$ марирут $($ Plan - Fact $)|=\varepsilon, \forall| \varepsilon \mid \gg 0$.

Тисячоліття реальний рейс, рух за маршрутом (навіть точно за геодезичними вимірами пунктів проходження) відрізняється за фактичними витратами ресурсів й отриманими ефектами, прибутками чи навпаки ситуаційними негараздами. Така прагматика (відхилення й реальні коливання чи локальні чи у цілому) ніколи не змінювали зусиль на прогнозування, передбачення, моделювання й перспективне планування (програмування засобами IT). Одночасно розроблялись паралельні організаційні дії для забезпечення функціональної стійкості (спеціальна багатокритеріальні закони управління в особливих випадках контрольованих відхилень з причин фактичних впливів ЗНОС).

\section{4. Мовні засоби real-time управління}

Опис математичних задач, що підтримує ПАК КМ-ПД після вводу завдання, потребує явного визначення наступних складових:

- фазові змінні на протязі кожного n-го процесу;

- вектор управління або кортеж керованих із зовні параметрів впливу;

- рівняння (символьні, алгебраїчні та логічні) процесу, що моделюємо; 
- обмеження, умови, наявні ресурси й запаси;

- цільова функція оптимізації (згортка багатьох критеріїв);

- робочі параметри, що контролюємо, оцінюємо, управляємо для отримання кінцевого багато параметричного результату;

- екстерна допомога в критичних обставинах роботи ПАК.

Користувач системи КМ-ПД при формуванні робочих моделей (архівних, розрахунково-базових, синтез-моделей режимів) виконує наступні типові операції: побудова оперативної моделі ПСМ на основі зовнішньої або внутрішньо-системної інформації; адаптація робочих моделей до факторів впливу ЗНОС; синтез РОМ з можливою подальшою адаптацією до умов ПЧК. Частину інформації КМ-ПД автоматично копіює та компілює за заздалегідь узгодженими рівнями інформаційного забезпечення. За допомогою мови директивно-програмного управління складаємо інші Big Data. Окреме індивідуальне коригування на кожному 3 означених фрагментів набуває якісні значення на формування цільової РОМ згідно завдання. Зовнішні дані мають структуру вхідних форматів. Внутрішні це програми з системнобінарною взаємодією в режимі «Хмара» для спілкування з віддаленими іншими IAS.

Найбільш важливим для забезпечення ефективності методу автоматизації виконання цих функцій і завдань $є$ етап первинної побудови архівної моделі для конкретних ITS. Таким чином вирішуємо цілеспрямування методу на головні організаційні питання: склад моделі M. QI. S; кількість і склад моделі M.RJ.S; принципи подання ER-схем; еквівалентування-заміщення і кодування інформації по восьми типам асоціативних груп. Початкова машинна обробка дозволяє заповнити архівну базу даних паралельно або раніше ніж закінчене форматування бази знань. За один сеанс IAS керує обробкою будь-якої кількість порцій визначальних даних. Обсяг сфери автоматизації дорівнює кількості, яка у міру готовності носіїв процесних форматів компонент (ПФК) надійшли в ПАК КМ-ПД. Побудова архіву виконується відповідно до наступної послідовності керуючих системних ПФК, що складають типові автоматні функції, а також групові уніфіковані завдання для ДУМ КМ-ПД.

Принципи структурної будови мови КМ-ПД аналогічні для всіх форм методу автоматизації виконання функцій і завдань управління 
процесами створення складених матеріалів. Найбільш повно у діскурсі IAS обговорюють дії та директиви, але стисло реалізують введення завдань. Аналогічно обєктно-орієнтованому програмуванню абстрактні організаційні класи визначаємо інструментально. Наприклад, синтезу розрахунково оперативних моделей (РОМ) це можливо описати у вигляді наступного програмного завдання.

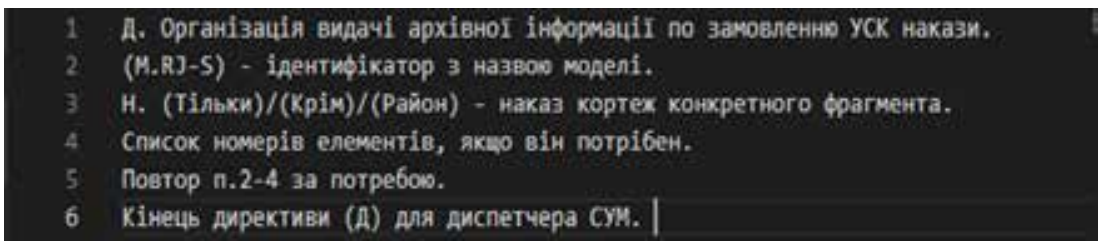

Така типізація реалізується засобами Java, Delphi, C\# та іншими інструментами конструктора. Перетворення директивного завдання стосовно формування в пам'яті ПАК КМ-ПД, робочої моделі в чіткі реалізуємо прискорено функції для розрахунків або іiі побудови на основі архівної інформації РБМ, розроблений метод автоматизації передбачає стислий пакет наступного складу:

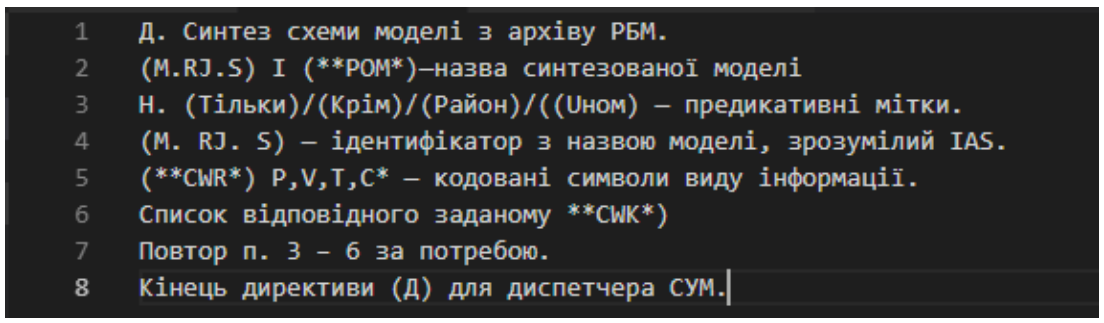

Мовний зрозумілий інструментарій та чітка технологія методу для реалізації функціоналу ергатичного моделювання спрямована на прискорення комплексу програмних дій за стандартом OSI.

Аналогічні процедури КМ-ПД - «бібліотека з'єднувачів» та синтезу робочих моделей утворюють інтегровану схему конкретної IT.

Крім операцій синтезу на стадіях САПР запропонований метод автоматизації враховує майбутні промислові технологічні процеси, наприклад, функції подрібнення, змішування, стиск, розвиток реак- 
ційного продукту. Ці майбутні на стадіях SCADA функції потребують знання керованих варіацій для ситуаційних змінних Р, V, T, С які залежать від $\mathrm{t}$ та $\theta^{0}$ температур. Склад та кінцевий продукт залежить від наявності або відсутності будь-яких домішок. Всі ці дані експерт - IAS отримує швидко без затримок у вигляді розрахунково-базових й оперативних моделей, що підтримані IT та засобами КМ-ПД.

Переваги впровадження КМ-ПД. Впровадження КМ-ПД покликане задовольняти потребу в повній та своєчасній інформації про формотворення ШКМ, щоб забезпечувати безпеку засобами IT за також достатню швидкістю виконання складних завдань, функцій та операцій включаючи методично організований, цілеспрямований, безперервний контроль якості, ефективності, надійності, результативності запропонованого комплексного методу автоматизації виконання функцій і завдань виробничого й організаційного мовного управління термодинамічними процесами створення перспективно складених матеріалів за допомогою лінгвістично-семіотичних інноваційних засобів ПАК КМ-ПД.

Таблиця 1

\section{Переваги впровадження КМ-ПД}

\begin{tabular}{|c|c|}
\hline \multicolumn{2}{|c|}{ Ефект від впровадження КМ-ПД } \\
\hline Прямий & Непрямий \\
\hline $\begin{array}{l}\text { 1. Зменшення трудомісткості процесу } \\
\text { обліку (виключення дублюючого } \\
\text { введення інформації; формування } \\
\text { єдиної бази даних); } \\
\text { 2. Зменшення чисельності } \\
\text { допоміжного персоналу для } \\
\text { обслуговування сховища в } \\
\text { актуальному стані. } \\
\text { 3. Економія матеріальних ресурсів, } \\
\text { які не витрачаються при імітаційному } \\
\text { моделюванні й обгрунтуванні } \\
\text { синергетичних ефектів корпоративної } \\
\text { мультиагентної самоорганізації. }\end{array}$ & $\begin{array}{l}\text { 1. Доступ до даних у режимі real-time } \\
\text { й процедур автоматизованих функцій } \\
\text { завдань для формотворення складених } \\
\text { моделей; } \\
\text { 2. Скорочення витрат робочого } \\
\text { часу, пов’язаного з зайвим пошуком } \\
\text { документообігу (підвищення } \\
\text { продуктивності праці: ефективне } \\
\text { використання робочого часу і } \\
\text { виконання якісно більшого обсягу } \\
\text { робіт) (2) ШКМ різних ITS; } \\
\text { 3. Оперативний контроль потоку } \\
\text { даних; } \\
\text { 4. Автоконтроль інформації; } \\
\text { 5. Підвищення рівня професійної } \\
\text { підготовки допоміжного персоналу } \\
\text { (матеріалознавців ITS). }\end{array}$ \\
\hline
\end{tabular}


За принципами стандартів OSI/IEC, що регламентують майбутній розвиток IT у формі широкомасштабного впровадження ПАК різноманітних галузей людської діяльності у попередніх підрозділах за темою визначені системо утворюючі механізми апарату автоматизації стосовно прагматики, семантики, онтології, граматики для задач термодинамічних процесів створення прогресивних (future) складених матеріалів за потреб й завдань ITS. Означена ієрархічна вкладеність гетерогенних шарів не обмежує подальший розвиток IT.

\section{5. Предикативна уніфікована логіка}

Запропоновані засоби КМ-ПД повинні відповідати додатково новітнім $(n e x t+1)$ критеріям майбутнього функціонування ITS. Увага до майбутніх термодинамічних явищ у незалежному ЗНОС вимагає описів кожного гетерогенного впливу природних коливань та імпульсних змін. Прогнозне передбачення тривимірного температурного поля за глобальних тенденцій планетарного масштабу може практично завершуватись наступними трьома наслідковими оцінками $\mathrm{S}(\mathrm{t}, \mathrm{x}, \mathrm{y}, \mathrm{z}, \mathrm{u})$ узагальненого стану.

$$
S_{i+1}=\left\{\begin{array}{c}
1-\text { істино, достовірно, не суперечить логіці стану; } \\
\sim-\text {-невизначено, є протирічча, частковий конфлікт; } \\
0-\text { точно нічого не змінює бо хибне. }
\end{array}\right.
$$

$\forall S_{i+1} \in S(t, x, y, z, u)$ - елемент наступного стану СДС, яка продовжує майбутній розвиток та відповідає всім критеріям й стандартам OSI/IEC.

Лінгвістичні семантичні інтеграції (2) можливо трактувати для локального ПЧК S як одночасні обставини 3D станів СДС за ключовими правилами

ЯКЩО \{1\} ТОДІ [звичайні, нормальні, позитивні, const БОН дії/рухи]; ЯКЩО \{ \} ТОДІ [позаштатні, небажані, змінні, var АКТ дії/рухи]; (3) ЯКЩО $\{0\}$ ТОДІ [протилежні, зворотні, негативні НОН дії/рухи].

Обидві дві (2) та (3) формалізації логічних висловлень IAS на різних ієрархічних рівнях характеризують один єдиний $\mathrm{S}$ об'єкт але з різних сторін знання реальних тенденцій або варіантів суспільних дій у межах ризиків та невизначеності факторів ЗНОС. 
Суспільне узагальнене стандартизоване знання можливо вважати об'єктивним або метамовою, що за тривалим досвідом не суперечить практиці. Вводимо символ метаімплікації « $\Rightarrow »$ у вигляді подвійної стрілки за напрямом. Вираз символьного опису $P_{i} \Rightarrow C_{j}$ можливо одночасно інтерпретувати «якщо посилка чи причина $P_{i}$ логічно-істина, тоді заключення чи наслідок $C_{j}$ також істина». Тому саме такі відношення між причинами та наслідком прийнято називати клаузой (clause) [4-6]. Клауза це метаопис 3 фіксацією за допомогою символу « $\Rightarrow$ відношення порядку за умов еквівалентності описів, що ліворуч та праворуч відносно показника. Логіка встановлює наступні для множин $\mathrm{A}, \mathrm{B}$, С три закони. Рефлективності $A \Rightarrow A$; Антисеметричності якщо $A \Rightarrow B$, то $\bar{B} \Rightarrow \bar{A}$; Транзитивності якщо $A \Rightarrow B$ та $B \Rightarrow C$, то $A \Rightarrow C$.

$\mathrm{У}$ випадках симетрії закони мають уніфікований опис «якщо $\mathrm{A}=\mathrm{B}$, то $\mathrm{B}=\mathrm{A} »$. Логіка висловлювань, для яких існує зв'язок між причиною та наслідком, інтерпретується як розширення логіки Буля [6-10]. Автоматизм переходу від тотожності Буля до істинності клауз, що засобами КМ-ПД моделюємо, полягає у знані незалежної системи аксіом логіки Буля. Відомо чотири закони з наступними назвами: комутативності, асоціативності, дистрибутивності, нуля та одиниці. Ключовим $\epsilon$ елементарне еталонне еквівалентне висловлювання. Воно потрібне завжди, коли ситуативно всі складні висловлювання можливо за допомогою означених логічних операцій над описами лінгвістичних клауз за допомогою еквівалентних кодів-операндів зводити дуже швидко, гнучко й точно до неї (clause Big Data тотожно істинна), наприклад $A \Rightarrow B \rightarrow A$.

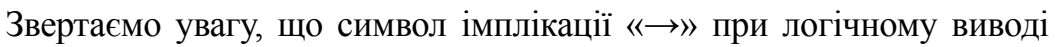
(доказу) КМ-ПД характеризує $\exists$ лише суб'єктивну оцінку групи експертів, що компетентні та вповноважені. Але їх думка не завжди співпадає 3 об'єктивною $\forall$ з причин областей існування (для одного випадки $-\exists \neq$ для всіх й кожного $\forall$ кванторів) підмножин в універсальній розширеній множині Всесвіту. Це візуалізують діаграми Вена [11].

У випадках гетерогенного множинного опису причинно наслідкові відношення об'єктивно описує клауза КМ-ПД

$$
P_{1}, P_{2}, \ldots, P_{i}, P_{i+1}, \ldots, P_{n} \Rightarrow C_{1} ; \mathrm{C}_{2} ; \ldots ; C_{j} ; \ldots C_{m},
$$

Де часткові форми лівих та правих часток називають хорновськими визначеннями. Такі описи можливо робити в сучасних ПАК типу Mat 
CAD, MATLAB, DataMinimg або там, де в бібліотеці програмування $\epsilon$ засоби логічних мов типу Пролог $[9,11]$.

\section{6. Ергатичний інтелект і автоматна якість}

В ПАК КМ-ПД уніфіковані процесорні дії ТПМ реалізуються автоматично за участю ПІМ відповідно до мовного завдання за директивно-командними принципами стислого виразу з явним замовчуванням попереднього контенту. Тому використання відносин $R_{i}(M E, \mathrm{TCC})$, $R_{i}(M I, B C), \quad R_{i}(\mathrm{TCC}, \mathrm{BC})$ в рамках фрагмента концептуальної бази (ФКБ) запропоновано відновлювати та розкривати засобами ПІМ. Ситуативно потрібні об'ємні описи КМ-ПД конкретизує за рахунок явних (по $S-, P-, R-, M$ - та А-ознаками) зв'язків в ланцюзі по узагальненим ідентифікаторам об'єктів IT, що моделюємо й прогнозуємо.

Розкриття внутрішніх відносин робимо 3 використанням $R_{0}(M A, C O C), R_{0}(M I, \mathrm{AC}), R_{0}(C O C, A C)$. Це дозволяє відповісти на всі уніфіковані кортежі, де питання, пов'язані з особливостями компонент-матеріалів складної системи.

Перехід від абстрактного кодового відношення $R(X \rightarrow B)=R(X, B)$ до уточнюючого його конкретними відносинами КМ-ПД здійснює зі застосування $S_{-}, P-, R-, M$ - та А-ознак. Аналіз куща поняття Х для всіх відносин, пов'язаних з концептом відносин пошукового об' єкта Ү, дозволяє при необхідності автоматично формувати асоціацію. За допомогою іiі зробимо перехід від $M E_{i}$ та $M E_{j}$ понять й далі до фрагментів або до їхніх елементів. Якщо сформована асоціація натяку, то можливий швидкий та прискорений пошук по стрілкам з відносинами $R(M E), R(M A), R(M I)$ $, R(T C C), R(C O C)$ лінгвістичних чи кодових найменуванням властивостей відповідного $\mathrm{S}$ об'єкта. Якщо сформована асоціація по суміжності, то при пошуку використовуємо пари відносин $R_{i}(T C C, \mathrm{BC})-\mathrm{R}_{\mathrm{j}}(\mathrm{MI}, \mathrm{BC})$ або $R_{0}(C O C, A C)-R_{0}(\mathrm{MI}, \mathrm{AC})$ в залежності від зовнішнього або внутрішнього типу опису прояву реальних властивостей.

Системна модель бази знань ЄІП представляємо узагальненим структурним графом $G(B, Q)[5]$, де достатній $B=\bigcup_{i \in I} V^{i}-$ вершинний базис, заданий підграфами $G_{i(k-1)}^{k-1}\left(V_{k}^{k-1} H_{i k}^{k-1}\right)$ в $G^{k}\left(V^{k}, H^{k}\right) \in G(B, Q)$; множина $Q=\bigcup_{k=1}^{n+1} \bigcup_{i k=1}^{r} H_{i k}^{k-1}-$ зв'язки, ребра чи дуги графа. Вони відобража- 
ють необхідні відношення $H_{i k}^{k-1}$ на множині $V^{k-1}$ підлеглого підграфа. Індекс ik визначає позицію (адресу) і число елементів $V^{k}$ множини, a $r=\sum i k$ характеризує число елементів вершинного базису сховища КМ-ПД.

Семантичні об'єкти, лінгвістичні змінні і дані (поняття, атрибути, значення) зберігаємо в дев'яти типах записів $[4,6]$. Тоді в рамках теми маємо опис, як верховий базис предметної області знання термодинамічних процесів у складних матеріалах з непересічних упорядкованих підмножин:

$$
D_{I J}=\bigcup_{i=1}^{l} \bigcup_{j=1}^{k} D_{i j}, \forall\left\{i j \mid D_{i j} \cap D_{i n} \equiv \varnothing ; D_{i j} \cap D_{m j} \equiv \varnothing\right\} .
$$

Для оптимізації процедури взаємодії з базою знань, нормативне $\bar{J}$ упорядкування виключає дублювання об'єму даних. Поняття СЕМ, ГТХ зазвичай $є$ термінальними або нуль-графами $G^{0}\left(V^{0}, H^{0}\right)$ для граматики перетворень на семантичній мережі. КМ-ПД для виконавчих ТПМ може сформувати складну, розчленовану структуру даних. Поняття МЕ, МА і МІ відображаємо графами $G^{k+1}\left(V^{k+1}, H^{k+1}\right)$, $G^{k}\left(V^{k}, H^{k}\right)$ і $G^{k-1}\left(V^{k-1}, H^{k-1}\right)$ відповідно.

Відносини доцільних типів в загальному випадку моделюємо k-парними підграфами і відображаються в ПАК КМ-ПД відповідними фрагментами семантичної мережі. Адресні відносини між записами в ланцюзі (головна - детальна) [3] засобами КМ-ПД встановлюються автоматично відповідно до логічної схеми накопичуваної бази знань. Такі моделі використовуємо при роботі з семантичною мережею ПАК КМ-ПД.

Головний запис визначає базову множину лінгвістичної змінної щодо обраної мети. Елементами базової множини можуть бути детальні записи в командах на виконання. Адресні посилання в зв'язках між семантичними об'єктами істотно підвищують швидкодію затребуваних ТПМ над лінгвістичними змінними. Збільшення числа $d_{i j} \in D_{I J}$ подовжує ланцюг і знижує швидкодію. Тому доцільна функціонально-математична алгебраїзація семантичних об'єктів, яка на обмежений таким чином коло питань [5] гарантує відповідні результати.

В описах теми використовуємо МЕ-поняття. Тоді зміст та об'єм моделей розкриваємо через МА- та МІ-поняття. В силу вкладеності $M E_{I} \supset M A_{J} \supset M I_{K}$ (детальні) поняття відношення і істинної особли- 
вості об'єктів відображаємо лише через властивості, які задані темою. Приклад опису через МА 1 =<верхній шар>, МА 2 -<середній шар>, MA $3=<$ низ-опора $>$, МА $4=<$ матеріал, що навантажуємо $>$ та інші $M A_{j}$ - поняття пояснює визначення $M E_{i}=<$ моделі елементів КСШ для планування засобами КМ-ПД геометрично описаних та механічно з'єднаних шарів.

\section{7. Адаптивна самоорганізація баз знань}

Трирівневе (МА-МІ-СЕМ) розкриття змісту МЕ-поняття в інших відносинах може бути неповним. Тоді експлікація на сукупності цих відносин може стимулювати додаткове завантаження нового кортежу ME-понять. Мікрооб'єкт таким же чином можна описати, розглядаючи його (і подібне йому) як складну МЕ-систему з обумовленою областю тематично модельних відносин. Адаптивний розвиток понять бази знань, що таким чином накопичуємо, забезпечує будь-який доцільний рівень деталізації задач моделювання СДС.

Відома тематична стратифікація IT з трирівневим системним розкриттям змісту не відповідає розгалуженим загальноприйнятим прийомам OSI класифікації за складом, структурою, функціями та іншими деталізуючими аспектам. Наш підхід заснований на формуванні засобами КМ-ПД автономних тематичних реляційних систем-моделей IT, що за певним досвідом IAS індивідуалізовані за кожним цільовим призначенням. ПІМ мають спільний топологічний базис (рис. 1) на множині понять. Він використовується методами актуалізації дій відповідно пошукового означення документу (ПОД). Топологічна єдність забезпечує перетворення інформації в рамках конкретних відносин (рис. 2) між МЕ-, МА, MI-, COC-, ТСС-поняттями і СЕМ- та ГТХ-атрибутами ЄІП системи КМ-ПД. Тема (сукупність цілей моделювання) в кодовій формі розкриває цілісний системний зміст. Опис його зафіксовано у пам'яті згідно конкретному графу $G(B, Q)$, що відображає лише динаміку IT обробки даних, які моделюють (заміщують) означені реальності об'єктів СДС.

Кожна реляційна модель $G(B, Q)$, що зберігається в СУТ КМ-ПД, класифікує інформацію на фізичні об'єкти $\mathrm{S}$, властивості Р, відносини $\mathrm{R}$, схеми алгоритмів A і робочі моделі М. Що в цілому забезпечує відповіді на питання по МЕ-темі. 3 цією метою семантичний об'єкт або 
запис в базі даних забезпечується відповідним S-, P-, R-, A-, M-ознакою. Тоді дуги семантичної мережі будуть конкретно (5 ознак) ідентифікувати тип $X_{i} R_{k} Y_{j}$ - відношення. Він ідентифікує категорію дії, зв'язку, функції між поняттями $X_{i}$ i $Y_{j}$ у логічному ланцюзі (ланцюг (рис. 1) адресних посилань між записом $X_{i}$ головним і всіма ії детальними $Y_{j} \forall j \in J$ частками). Для комплексних досліджень і забезпечення якості розрахунків доцільні в СУТ КМ-ПД (рис. 2) знання не тільки про матеріальні S, а й про P-,R-, M-, A- - інтелектуальні об'єкти обізнаності IAS ПЕВO.

Обсяг допоміжних знань, які оптимізують застосуванням типових моделей і алгоритмічних автоматизованих рішень, істотно менше глобального обсягу Internet базових знань по досліджуваному фізичного об'єкту. Однак такий поділ є умовним. Дійсно моделі і алгоритми доцільні, якщо вони адекватно відображають фізичний об'єкт. Тому 3 урахуванням взаємозв'язку (рис. 2) потенційна потужність даної організації бази знань КМ-ПД із запропонованими базовими 5-ознаками оцінюється добутком

$$
(S \times P \times R \times M \times A)^{5} .
$$

Отже, дана база знань (рис. 1) має достатню різноманітність та задовольняє зазначеним вимогам, на експлуатаційні потоки майбутніх запитів.

Перелік тем (рис. 2) універсальних відношень та властивостей, необхідних для повного опису КСЦМ об'єкта та оточуючого ії ЗНОС, обирається в залежності від призначення та цілей застосування ПАК КМ-ПД.

Системою мови універсальних структурно-функціональних конструкцій виду <якщо А (опис явищ та об'єктів) тоді В (опис послідовних дій)> (табл. 2) можуть слугувати відповідні кортежі ПАК КМ-ПД.

Дана багатоцільова система по мірі введення індивідуальної інформації може використовуватись IAS для відповіді на різноманітні питання користувачів ПЕВО в тому числі самої моделюючої системи КМ-ПД.

При формуванні ССМ вихідна семантична інформація аналізується згідно наступної семантичної структури опису, яка дає відповідь на питання.

При обробці КСЦМ та асоціативно пов'язаних фрагментів КМ-ПД використовуються різні ситуаційно-ефективні методи, засоби, алгоритми та правила трансформації вихідних даних в семантично вірні (логічно істинні) наслідки. 


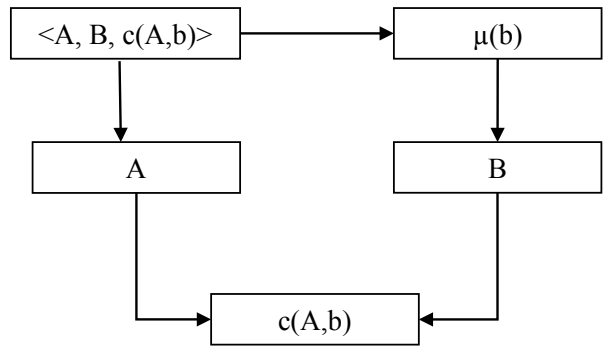

Рис. 1. Типова структура взаємозв'язків для організації ланцюгового запису об'скта у фрагментах файлів банка даних ПАК КМ-ПД

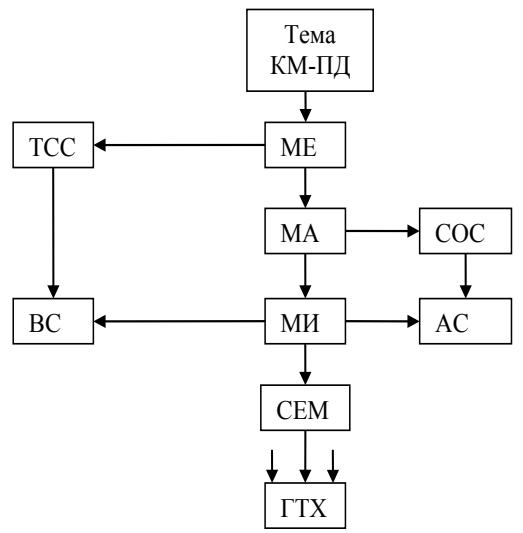

\section{Рис. 2. Системна модель бази знань ПАК КМ-ПД}

Символьні кортежі методами причинно-наслідкових залежностей автоматично створюються згідно завдань на основі висновків: по аналогії, ознаці ситуації, структурі наявних знань та відношень. Алгебраїзація кодових зв'язків визначена в пам'яті ПВМ КМ-ПД згідно уніфікованих структур (рис. 1 та 2).

Побудова моделі здійснена виокремленням найбільш характерних, істотних особливостей кожного означеного об'єкта натури. Цільова динамічна взаємодія структур, з різних сторін (6) описують реальну систему відношень за методами моделювання складних динамічних систем. Згідно завдань, це дозволяє формувати адекватні робочі 


\section{Таблиця 2}

\section{Опис парних еквівалентів мови зв'язаного змісту кортежів}

\begin{tabular}{|c|c|}
\hline \multicolumn{2}{|c|}{ Причинно наслідковий зміст ситуативно-варіаційних описів кортежів у ПЧК } \\
\hline$A=\left(a_{1}, a_{2}, \ldots, a_{n}\right)$ опис явищ та об'єктів & $B=\left(b_{1}, b_{2}, \ldots, b_{m}\right)$ опис послідовних дій \\
\hline $\begin{array}{l}a_{1}-\text { визначення предмета, кваліфіка- } \\
\text { ція (< що називається як><що }-\epsilon \text { що>, } \\
<\text { що є чим>); }\end{array}$ & $b_{1}$ - АКТ дії (Що виконує що); \\
\hline $\begin{array}{l}a_{2}-\text { приналежність класу ((що } \\
\text { ділиться на що), що є частиною чого), } \\
\text { (що відноситься до чого)); }\end{array}$ & $\begin{array}{l}b_{2} \text { - причина дії (що зроблено чому, } \\
\text { навіщо, для чого); }\end{array}$ \\
\hline $\begin{array}{l}a_{3} \text { - мета застосування ((що застосо- } \\
\text { вується де, як, навіщо, чому, для чого)); }\end{array}$ & $\begin{array}{l}b_{3} \text { - визначення результату дії (що } \\
\text { стало чим); }\end{array}$ \\
\hline $\begin{array}{l}a_{4}-\text { час та умови подій ((коли, дата, } \\
\text { ситуація, умови)); }\end{array}$ & $b_{4}$ - оцінка інформації (що керує чим); \\
\hline $\begin{array}{l}a_{5}-\text { місцезнаходження ((що де знахо- } \\
\text { диться), (що де функціонує)); }\end{array}$ & $\begin{array}{l}b_{5} \text { - характеристика функцій (що } \\
\text { здійснюється, яким чином); }\end{array}$ \\
\hline $\begin{array}{l}a_{6}-\text { склад та будова ((що з чого скла- } \\
\text { дається), (що є частиною чого)); }\end{array}$ & $\begin{array}{l}b_{6}-\text { визначення умов (при яких умо- } \\
\text { вах та ситуаціях); }\end{array}$ \\
\hline $\begin{array}{l}a_{7} \text { - опис функціонування ((що і як } \\
\text { здійснюється)); }\end{array}$ & $\begin{array}{l}b_{7}-\text { умови існування майбутніх подій } \\
\text { (що буде чим); }\end{array}$ \\
\hline $\begin{array}{l}a_{8}-\text { виникнення та поява ((що де } \\
\text { виникає, з чого, як)); }\end{array}$ & $\begin{array}{l}b_{8} \text { - умови, які мали місце в минулому } \\
\text { (що було раніше); }\end{array}$ \\
\hline $\begin{array}{l}a_{9}-\text { причинно-наслідкові відношення } \\
((\text { сл слідує з чого, за рахунок чого)); }\end{array}$ & $\begin{array}{l}b_{9} \text { - характеристика процесів (що } \\
\text { виникає з чого і як); }\end{array}$ \\
\hline $\begin{array}{l}a_{10} \text { - перетворення та зміна (( що в що } \\
\text { перетворюється), (що яким стає)); }\end{array}$ & $\begin{array}{l}b_{10}-\text { опис змін (що перетворюється у } \\
\text { що), (що стає яким); }\end{array}$ \\
\hline $\begin{array}{l}a_{11} \text { - властивості та характеристики } \\
\text { якості (( що чим наділене)); }\end{array}$ & $\begin{array}{l}b_{11} \text { - оцінка результату (що сходиться } \\
3 \text { чим), (що відрізняється від чого); }\end{array}$ \\
\hline $\begin{array}{l}a_{12}-\text { порівняння та співставлення (( } \\
\text { що відрізняється від чого), (що з чим } \\
\text { сходиться)). }\end{array}$ & $\begin{array}{l}b_{12}-\text { кваліфікація властивостей (що } \\
\text { володіє чим, якою якістю). }\end{array}$ \\
\hline $\begin{array}{l}a_{n}-\text { резервна додаткова мітка поняття, } \\
\text { що може характеризувати ще специ- } \\
\text { фічні на початку чомусь не зафіксовані } \\
\text { сутності реальної природи. }\end{array}$ & $\begin{array}{l}b_{m}-\text { аналогічно } a_{n} \text { додаткова мітка } \\
\text { (групи понять) потребою розвитку }\end{array}$ \\
\hline
\end{tabular}


моделі, здійснювати пошук відповідей в рамках конкретної ситуативної задачі за темою діяльності IAS ПЕВО.

\section{8. Висновки}

1.Враховуючи відкритість СДС та еволюційний розвиток за етапами (епохами, періодами, кроками) реорганізації їх моделей бази КМ-ПД забезпечують відповідні соціокомунікативні формотворення й зміни (коригування, уточнення) атрибутів та параметрів, включаючи необхідні інфологічні моделі.

2. Глобальні планетарні проблеми безпеки життя ноосфери, флори, фауни для всіх представників біорізноманіття раніше «нормальних» екологічно «чистих» природних систем набувають все більш загрозливі форми. Соціалшьна комунікація повинна знати конструктивні техніко-технологічні рішення для повсякденних цілеспрямованих дій, що також ретельно й за багатьма критеріями моделюємо, оцінюємо, розподіляємо закони управління у просторово-часових контінуумах планети.

3. Парниковий ефект запущено всіма галузями людської діяльності у сучасних ринкових відношеннях іiі глобалізації. Висновок лише один, треба негайно активізувати соціальний інтелект, щоб починати утилізацію накопичених запасів забруднень 3 вуглицево-органічними чисельними речовинами.

\section{Список літератури:}

1. Баранов Г.Л., Мнацаканян М.С., Комісаренко О.С. Моделювання процесів МITC зі змінними ситуаціями у часі та просторі. Polish journal of science. 2018. Vol. 1. No. 12. P. 30-38.

2. Баранов Г.Л., Комісаренко О.С. Процесні інфологічні моделі в задачах гетерогенної взаємодії складних динамічних систем та нестаціонарного середовища. Вісник Національного транспортного університету. 2019. Вип. 1(40). С. 3-12.

3. Баранов Г.Л., Комісаренко О.С. Технологія інтеграції гетерогенних процесів моделювання формотворення матеріалів для майбутніх транспортних систем. Вісник Наџіонального транспортного університету. 2018. Вип. 1(39). С. 24-33.

4. Кравчук В.І., Баранов Г.Л., Прохоренко О.М., Комісаренко О.С. Інформатизація агропромислового комплексу із застосуванням розгалужених сервісів: стан і перспективи розвитку. Техніко-технологічні аспекти розвитку та випробування нової техніки і технологій для сільського господарства Украйни : Зб. наук. пр. УкрНДІПВТ. 2018. Вип. 24(38). С. 202-213. 
5. Кравчук В.І., Баранов Г.Л., Комісаренко О.С. Ергатичне випробування у просторі та часі комплексних техніко-технологічних рішень керованого землеробства. Техніко-технологічні аспекти розвитку та випробування нової техніки і технологій для сільського господарства України : Зб. наук. пр. УкрНДІПВТ. 2018. Вип. 23(37). С. 14-27.

6. Кравчук В.І., Баранов Г.Л., Комісаренко О.С. Інформаційна технологія прогнозування та випробування майбутньої аграрної техніки. Технікотехнологічні аспекти розвитку та випробування нової техніки і технологій для сільського господарства України : Зб. наук. пр. УкрНДІПВТ. 2018. Вип. 22(36). С. 27-35.

7. Баранов Г.Л., Комісаренко О.С., Чака О.Г. Інфологічне моделювання технологій створення матеріалів для футорологічних конструкцій та систем. Метрологія та прилади. 2018. № 6(74). С. 53-58.

8. Баранов Г.Л., Комісаренко О.С. Методологічні основи моделювання процесів формотворення інноваційних матеріалів аерокосмічної технології. Аерокосмічні технології. 2017. Вип. 2(02). С. 5-11.

9. Комісаренко О.С. Результати взаємодії в системі В4С-Hf при різних термодинамічних умовах. The scientific heritage. 2017. № 12(12). Р. 2. Р. 107-117.

10. Комісаренко О.С., Макаров В.О. Питання інтеграції гетерогенних процесів для майбутніх транспортних систем. Управління проектами, системний аналіз та логістика. Серія: «Технічні науки». 2017. Вип. 20(41). Ч. 1. С. 50-57.

11. Баранов Г.Л., Комісаренко О.С. Інфологічне моделювання складних процесів формотворення нових речовин. Моделювання та інформаційні технологіï : зб. наук. пр. Нац. акад. наук України, Ін-т пробл. моделювання в енергетиці ім. Г.С. Пухова. 2018. № 85. С. 12-22.

\section{References:}

1. Baranov H.L., Mnatsakanian M.S., Komisarenko O.S. (2018). Modeliuvannia protsesiv MITS zi zminnymy sytuatsiiamy u chasi ta prostori [Modeling of MITS processes with changing situations in time and space]. Polish journal of science. Vol. 1. No. 12. P. 30-38.

2. Baranov G.L., Komisarenko O.S. (2019). Procesni infologichni modeli $\mathrm{v}$ zadachax geterogennoyi vzayemodiyi skladnyx dynamichnyx system ta nestacionarnogo seredovyshha [Process infological models in problems of heterogeneous interaction of complex dynamic systems and non-stationary environment]. Visnyk Nacionalnogo transportnogo universytetu. Vyp. 1(40). S. 3-12.

3. Baranov G.L., Komisarenko O.S. (2018). Texnologiya integraciyi geterogennyx procesiv modelyuvannya formotvorennya materialiv dlya majbutnix transportnyx system [Technology of integration of heterogeneous modeling of materials formation for future transport systems]. Visnyk Nacionalnogo transportnogo universytetu. Vyp. 1(39). S. 24-33.

4. Kravchuk V.I., Baranov G.L., Proxorenko O.M., Komisarenko O.S. (2018). Informatyzaciya agropromyslovogo kompleksu iz zastosuvannyam rozgaluzhenyx servisiv: stan i perspektyvy rozvytku. [Informatization of agro-industrial complex 
with the use of branched services: state and prospects of development]. Texnikotexnologichni aspekty rozvytku ta vyprobuvannya novoyi texniky i texnologij dlya silskogo gospodarstva Ukrayiny: Zb. nauk. pr. UkrNDIPVT. Vyp. 24(38). S. 202-213.

5. Kravchuk V.I., Baranov G.L., Komisarenko O.S. (2018). Ergatychne vyprobuvannya u prostori ta chasi kompleksnyx texniko-texnologichnyx rishen kerovanogo zemlerobstva [Ergatic testing in space and time of complex technical and technological solutions of managed agriculture]. Texniko-texnologichni aspekty rozvytku ta vyprobuvannya novoyi texniky $i$ texnologij dlya silskogo gospodarstva Ukrayiny: Zb. nauk. pr. UkrNDIPVT. Vyp. 23(37). S. 14-27.

6. Kravchuk V.I., Baranov G.L., Komisarenko O.S. (2018). Informacijna texnologiya prognozuvannya ta vyprobuvannya majbutnoyi agrarnoyi texniky[Information technology of forecasting and testing of future agrarian technology]. Texniko-texnologichni aspekty rozvytku ta vyprobuvannya novoyi texniky i texnologij dlya silskogo gospodarstva Ukrayiny: Zb. Nauk pr. UkrNDIPVT. Vyp. 22(36). S. 27-35.

7. Baranov G.L., Komisarenko O.S., Chaka O.G. (2018). Infologichne modelyuvannya texnologij stvorennya materialiv dlya futorologichnyx konstrukcij ta system [Infological modeling of materials creation technologies for futrological structures and systems]. Metrologiya ta prylady. № 6(74). S. 53-58.

8. Baranov G.L., Komisarenko O.S. (2017). Metodologichni osnovy modelyuvannya procesiv formotvorennya innovacijnyx materialiv aerokosmichnoyi texnologiyi [Methodological bases of modeling of formation processes of innovative materials of aerospace technology]. Aerokosmichni texnologiyi. Vyp. 2(02). S. 5-11.

9. Komisarenko O.S. (2017). Rezultaty vzayemodiyi v systemi B4C-Hf pry riznyx termodynamichnyx umovax [The results of the interaction in the B4C-Hf system under different thermodynamic conditions]. The scientific heritage. № 12(12). P. 2. P. 107-117.

10. Komisarenko O.S., Makarov V.O. (2017). Pytannya integraciyi geterogennyx procesiv dlya majbutnix transportnyx system [The issue of integrating heterogeneous processes for future transportation systems]. Upravlinnya proektamy, systemnyj analiz ta logistyka. Seriya: "Texnichni nauky». Vyp. 20(41). Ch. 1. S. 50-57.

11. Baranov G.L., Komisarenko O.S. (2018). Infologichne modelyuvannya skladnyx procesiv formotvorennya novyx rechovyn [Infological modeling of complex processes of formation of new substances]. Modelyuvannya ta informacijni texnologiyi: zb. nauk. pr. Nacz. akad. nauk Ukrayiny, In-t probl. modelyuvannya $\mathrm{v}$ energetyci im. G.Ye. Puxova. № 85. S. 12-22. 